\title{
Perceptual variety linguistics: Jerezano speakers' concepts and perceptions of phonetic variation in western Andalusian Spanish ${ }^{1}$
}

\author{
Jannis Harjus \\ Universität Innsbruck (Austria) \\ jannis.harjus@uibk.ac.at ORCID: http://orcid.org/0000-0001-5150-6106
}

\begin{abstract}
Submitted: 17/03/2017. Accepted: 05/07/2017. Published online: 29/01/2018
Citation / Cómo citar este artículo: Harjus J. (2017). Perceptual variety linguistics: Jerezano speakers' concepts and perceptions of phonetic variation in western Andalusian Spanish. Loquens, 4(2), e042. doi: http://dx.doi.org/10.3989/loquens.2017.042
\end{abstract}

\begin{abstract}
This article deals with the metalinguistic knowledge of Jerezano speakers about the phonetic variation within the Andalusian dialectal continuum, applying the perceptual variety linguistics. In particular, we investigate the metalinguistic knowledge about a possible phonic norm in western Andalusia that presumably diverges from the national standard of Peninsular Spanish. Methodologically, we distinguish between representations based on concrete perceptions and metalinguistic representations, in order to know if there are divergences between permanent metalinguistic knowledge and knowledge based on direct perceptions: both results show a clear division between a ceceante (Jerez and rural western Andalusia) and another seseante zone (the capital of Seville and the other provincial capitals of western Andalusia). Consequently, the speakers themselves believe in the non-existence of a Sevillian norm based on seseo for the community of speech analyzed. This metalinguistic knowledge strengthens more recent socio-phonic data on the speech community of Jerez. Therefore, the successful combination of the perspectives of linguists and the speakers themselves constitutes a very promising methodological triangulation for the phonetic-phonological research of the Hispanic varieties in general.
\end{abstract}

Keywords: perceptual variety linguistics; mental representations; perceptual phonetics; salience; Andalusian dialectology.

RESUMEN: Lingüistica perceptiva de la variación: Los conceptos y las percepciones de los hablantes jerezanos de la variación fonética en el andaluz occidental.-Este artículo trata del saber metalingüístico de hablantes jerezanos acerca de la variación fónica dentro del continuo dialectal andaluz, aplicando la lingüística perceptiva de la variación. En particular, se investiga el saber metalingüístico acerca de una posible norma fónica del andaluz occidental que presuntamente diverge del estándar nacional del español peninsular. Metodológicamente, se distingue entre representaciones basadas en percepciones concretas y representaciones metalingüísticas abstractas, con el fin de saber si existen divergencias entre el saber metalingüístico permanente y el saber basado en percepciones directas: ambos resultados demuestran una clara división entre un ámbito ceceante (Jerez y Andalucía occidental rural) y otro seseante (Sevilla capital y las otras capitales de provincia de Andalucía occidental). Por consiguiente, los propios hablantes creen en la inexistencia de una norma sevillana basada en el seseo para la comunidad de habla analizada. Este saber metalingüístico fortalece datos socio-fónicos más recientes sobre el habla de Jerez. Por lo tanto, la fructífera combinación de las perspectivas de lingüistas y de los propios hablantes constituye una triangulación metodológica muy prometedora para la investigación fonético-fonológica de las variedades hispánicas en general.

Palabras clave: lingüística perceptiva de la variación; representaciones mentales; percepción fonética; saliencia; dialectología andaluza.

\footnotetext{
${ }^{1}$ We follow in this contribution the research design and analysis of Harjus (2018), based on his PhD thesis defended at University of Mainz (Harjus, 2016).
}

Copyright: $(2017$ CSIC This is an open-access article distributed under the terms of the Creative Commons Attribution License (CC BY) Spain 3.0. 


\section{INTRODUCTION: THE RESEARCH OF PHONIC CHARACTERISTICS IN THE SPEECH COMMUNITY OF JEREZ DE LA FRONTERA}

In Hispanic linguistics, it is agreed that the different Andalusian varieties are among the best investigated within the Hispanic dialects (Congosto Martín, 2009, p. 85), especially with respect to their phonetic-phonological characteristics. The research on the variation in the speech community of Jerez also does not constitute a desideratum within the Hispanic linguistics. Although García-Amaya (2008) rightly notes that it "is relatively understudied" (p. 54), in recent years many works have been dedicated to different variational aspects about local variety (see Alvar, Llorente, \& Salvador, 1973; Carbonero Cano et al., 1992; García-Amaya, 2008; Harjus, 2017, 2018; Henriksen \& García-Amaya, 2012; and Henriksen $\&$ Willis, 2010). With the increase of these (socio-) phonetic studies on the speech community, doubts have also arisen regarding the most characteristic phonic elements of Spanish in Jerez.

Scientific research on the Jerezano variety began with the Atlas lingüístico y etnográfico de Andalucia (ALEA; Alvar et al., 1973), in which the realization [ $\theta$ ] for the Spanish phonemes $/ \mathrm{s} /$ and $/ \theta /$ within the speech community is highlighted, which therefore lies within the ceceo $^{2}$ area (map 1705, p. 1580). This traditional conclusion of the ALEA on the dephonologization of $/ \mathrm{s} /$ and $/ \theta /$ in Jerez is modified by Carbonero Cano et al. (1992), who find, especially among the speakers of a medium and higher educational level, many speakers who tend towards a seseante realization of the neutralization of $/ \mathrm{s} /$ and $/ \theta /$, since they see more prestige for seseo $^{3}$ than for ceceo in the speech community:

el hablante jerezano no es decididamente seseante o ceceante. Sin embargo, las diferencias por el nivel sociocultural son plenamente clarificadoras de lo que ocurre; puede observarse que el índice de seseo es mayor cuanto más se sube de nivel sociocultural y que, correlativamente, el ceceo aumenta en los niveles menos cultos de la población (p. 24).
From the conclusions of the study by Carbonero Cano et al. (1992) and other studies on the Andalusian varieties, Villena Ponsoda $(1996,2012)$ and Carbonero Cano $(1985,2003)$ deduce that the influence of the linguistic variety of urban Seville on the western zone, including the Jerezano speakers, is enormous: "The urban variety of Seville (norma sevillana) is accepted as a model of pronunciation for western varieties" (Villena-Ponsoda, 2008, p. 144). ${ }^{4}$ According to Villena-Ponsoda (2008) and Carbonero Cano (2003), this supposed regional standard would be based mainly on the seseante pronunciation of $/ \mathrm{s} /$ and $/ \theta / 5$ and causes both a reduction of the influence of a Spanish national standard, that is to say the distinction between $/ \mathrm{s} /$ and $/ \theta /$, and the rejection of allegedly discredited phenomena of western Andalusian varieties, ${ }^{6}$ especially сесеo, in the western urban centers. Just the opposite is demonstrated by another socio-philosophical study on the speech community of Jerez. García-Amaya (2008, p. 65) investigates a social network of speakers and concludes that the realization of seseo in the Jerezano variety of spoken Spanish is almost nil. Like García-Amaya (2008), Harjus (2018) hardly finds any seseante realizations in the last socio-phonological study on the local speech community, even among the most educated speakers and neither in close communicative situations nor in situations of distance. Thus, the results of the two most recent studies on the Jerezano variety deny by tendency not only the old data of Carbonero Cano et al. (1992) on phonological neutralization in Jerez, but also a regional standard of Sevillian origin for the local speech community: the data indicate that Jerezano speakers tend to perform сесеo or, especially, university-educated speakers, to maintain the distinction between $/ \mathrm{s} /$ and $/ \theta /$ of the national standard of peninsular Spanish.

The flamencologist de la Plata (1993) mentions from a nonscientific perspective the idea of a Jerezano speech community that tends towards ceceo and totally rejects the use of seseo: "En Jerez no se sesea, como en Sevilla, o en otros lugares" (p. 18). As this position contradicts the scientific position of Carbonero Cano et al. (1992), in this contribution we are convinced that it is worthwhile to delve deeper into an investigation of the linguistic knowledge of the speakers who are not specialized in linguis-

\footnotetext{
2 It is a very simplified commonplace in Hispanic linguistics that the term ceceo refers to the dephonologization of the standard Spanish phonemes $/ \mathrm{s} /$ and $/ \theta /$ in favor of $[\theta]$. Nevertheless, the process itself was much more complicated: From a diachronic perspective, the $c e c e o$ is not a consequence of the dephonologization of $/ \mathrm{s} /$ and $/ \theta /$, but a realization of the phoneme /s/ that resulted from the restructuring of the complex Spanish medieval sibilants. Consequently, ceceante and seseante speakers never had a distinguishing system like that of the standard of European Spanish (see Harjus, 2018).

3 The term seseo refers to the opposite phenomenon of ceceo, realizing /s/. As ceceo, seseo is not a consequence of the dephonologization of $/ \mathrm{s} /$ and $/ \theta$ / either. It is a realization of the phoneme $/ \mathrm{s} /$ that resulted from the restructuring of the complex Spanish medieval sibilants.

4 In different works, Villena Ponsoda (2008, 2012) and Hernández-Campoy and Villena-Ponsoda (2009) apply the term diaglossia (Auer \& Hinskens, 1996) to the Andalusian variety continuum. Critical comments on the Andalusian version of the scheme are in Harjus (2018).

5 According to Villena-Ponsoda (2008), the Sevillian norm is based not only on seseo, but also on the phonic features of the fricativization [S] of the Spanish affricate $/ \mathrm{t} /$, of the aspiration of the $/ \mathrm{x} /$ and of the weakening of the implosive $/ \mathrm{s} /(\mathrm{pp}$. 157-158).

6 In this contribution, we follow the simplified division of a two-zone Andalusia - an eastern one and a western one-of Villena Ponsoda (for example, 2008). In reality, we cannot maintain this division: yet the ceceo-seseo-distinction isogloses of the ALEA (Alvar et al., 1973) indicate another course of the Andalusian dialects boundaries. So if we mention salient features from the eastern or western parts, the reader has to know that this is only for a better clarity in our argumentation.
} 
tics. We think that their contributions can help us to clarify the somewhat contradictory results of the descriptive studies about the Jerezano speech community. Therefore, we want to investigate what the local speakers, who are not engaged by profession or interest in linguistics, know about the phonic varieties of western Andalusian Spanish in general and about a supposed Sevillian regional standard in their local speech community in particular. Therefore, the linguistic modality and the questions about the Sevillian regional standard for the local speech community will be analyzed from the point of view of the speakers themselves, applying the recent perceptual variety linguistics (Harjus, 2018; Krefeld \& Putska, 2010; Pustka, 2007; Postlep, 2010a). This subdiscipline of variety linguistics will be described in Section 2. Then we will explain the methodical basis of this article and offer both the analysis and the discussion of the results of the research.

\section{PERCEPTUAL VARIETY LINGUISTICS}

\subsection{Metalinguistic concepts: the differentiation between linguistic attitudes and perceptions}

Following the sociolinguistic parameters, at the end of last century studies that take into account the metalinguistic ideas of Spanish speakers began to emerge: metalinguistic utterances are linguistic statements that refer to something linguistic (Gauger, 1976, p. 44). However, metalinguistic research on Andalusian varieties focuses exclusively on the attitudinal aspects ${ }^{7}$ and thus restricts the term metalinguistic consciousness to the attitudinal aspect, although Schlieben-Lange (1991, p. 25) points out that metalinguistic consciousness, despite being interrelated with attitude, forms another part of cognitive consciousness. Interesting regarding this contribution seems to be the idea that metalinguistic consciousness leads the speakers to identify themselves with a certain linguistic variety and helps them in the social categorization of speakers in different communicative situations (Scharloth, 2005, p. 15). However, it should not be forgotten that the comments of speakers about their linguistic consciousness do not always have to be conscious (Gauger, 1976 , p. 55). Therefore, several linguists (Krefeld \& Pustka, 2010; Preston, 1999) prefer to differentiate the meta- linguistic consciousness from the supposedly more conscious metalinguistic knowledge. Consequently, this contribution understands the metalinguistic consciousness as the basis of all concepts of metalinguistic knowledge. Therefore, the term is subdivided into linguistic attitude and metalinguistic knowledge. The aspect of metalinguistic knowledge, not restricted to the attitudinal aspect, is very little investigated within Spanish linguistics, as Serrano Morales (2001) points out: "In the Hispanic context, however, such works are practically nonexistent" (p. 2). For the Andalusian varieties, it even represents a desideratum.

In general, the scientific history of the metalinguistic perspective of the speakers themselves, despite having a modest beginning in the past, ${ }^{9}$ is relatively recent. For the first time, Preston $(1986,1989)$ and Niedzielski and Preston (2000) focused on the research of speakers' ideas about linguistic variation. According to Preston (2005, p. 149), the goal of the so-called perceptual dialectology is to clarify the cognitive knowledge of speakers about linguistic variation through the analysis of conscious and unconscious reactions to perceived spoken language. However, adaptations of the perceptual dialectology in the Hispanic domain are scarce: ${ }^{10}$ "While there is growing interest in the investigation of the perception of dialect variation in the United States, such research related to Spanish has not been very productive" (Díaz-Campos \& Navarro-Galisteo, 2009, p. 181). The perceptual variety linguistics, then, broadens the theoretical basis of perceptual dialectology. While perceptual dialectology focuses on diatopic variation and, following the English term dialect in the American tradition, on the speakers' linguistic attitudes as an element of sociolinguistics, perceptual variety linguistics extends this range by social and situational variations (see Krefeld \& Pustka, 2010, p. 10).

Krefeld (2005, p. 162) is the first to use the term Perzeptive Varietätenlinguistik (perceptual variety linguistics), which seeks to clasp the entire variation system from the speakers' point of view. ${ }^{11}$ Here, it is necessary to demonstrate the relationship between metalinguistic knowledge and concrete speech, which are mutually conditioned by a circular process between linguistic production and perception (Postlep, 2012, p. 89). Following Pustka (2007, p. 18), we believed that speakers modify their linguistic competence through perceptions throughout their life. This is why it is very important, besides

\footnotetext{
7 Although the linguistic attitudes of Andalusian speakers are often the subject of sociolinguistic research (e.g., Moyá Corral \& García Wiedemann, 1995; Narbona Jiménez, 2013), most of these studies focus only on the attitude of urban Sevillian speakers (e.g., Díaz Salgado, 2002; Ropero Núñez \& Pérez Santamaría, 1998).

${ }^{8}$ It should be admitted that, apart from Harjus (2018), also Torres Montes (1997, p. 635) distinguishes between a cognitive and an affective aspect in investigating linguistic consciousness and attitudes in the Almerian speech community.

9 Interest in the knowledge of nonspecialist speakers about linguistic variation in general goes back to the early and mid-20th century in the Netherlands (e.g., Weijnen, 1846/1999) and in Japan (e.g., Sibata, 1959/1999). However, most linguists involved in the subject at that time (e.g., Grootaers, 1964/1999) still rejected the ideas of the speakers because they are often not similar to the conclusions by scientists.

10 To date, the following works related to the perceptual dialectology exist in the Hispanic context: Serrano Morales, 2001; Alfaraz, 2002; Moreno Fernández and Moreno-Fernández, 2002; Boomershine, 2006; Erdösová, 2011. For more information on the state of the art for Hispanic linguistics see Harjus (2018).

11 At the moment there are only few works related to the Hispanic field based expressly on perceptual variety linguistics (Brade, 2010; Guzmán, 2010; Harjus, 2018; Postlep, 2010a, 2012). See, for more information about the state of the art, Harjus (2018).
} 
from investigating linguistic production, to analyze the speakers' perception, which precedes production from childhood: "Die Perzeption geht der Produktion fast immer voraus" (Krefeld \& Pustka, 2014, p. 12). Chomsky (1980) already indicates that it is not only necessary to investigate the linguistic production of the speakers, but also their linguistic knowledge. In this sense, he speaks of linguistic and mental representations of an ideal speaker who knows how to categorize grammatical elements (p. 5). Within the linguistics of variation it is a commonplace that a homogeneous speech community with ideal speakers (Chomsky, 1980, p. 25) does not exist. Accordingly, Pustka (2007, pp. 9-11; 2008, pp. 214-215) and Krefeld and Pustka (2010, pp. 10-16) include mental representations of the linguistic variation in the part of speakers' linguistic knowledge, representations that are subdivided into an abstract variational knowledge that a speaker can manifest without an external stimulus and another concrete metalinguistic knowledge about variation that is based on direct perceptions. Along with the Chomskian competence then, according to Krefeld and Pustka (2010, p. 11), there is also knowledge about the variation in a given language.

\subsection{About the necessity to distinguish between abstract cognitive concepts and concrete perceptions}

Although they exert a mutual influence, it is important to distinguish between the terms of concept and perception, since they constitute two fundamental theoretical pillars of the perceptive linguistics of variation. As already mentioned, abstract representations or concepts are part of the metalinguistic knowledge and are also present without concrete stimuli. Therefore, they are part of the permanent metalinguistic knowledge and belong to the langue. Contrary to abstract concepts, concrete perceptions belong to the parole. Consequently, we distinguish between abstract representations and representations based on concrete perceptions (Krefeld \& Pustka, 2010, p. 14).

However, it should be mentioned that all representations, including abstract ones, are based on concrete perceptions and in a constant process of change through each communicative experience. Additionally, concrete perceptions are controlled by abstract representations, whereby both are reciprocal (Krefeld \& Pustka, 2010, p. 14). This relationship does not prevent the speakers from maintaining strong stereotypes about certain varieties, due to extralinguistic influence and the maintenance force of these in the abstract representations. As a result of this possible ignorance, it has often been shown that some speakers emphasize in their mental maps dialectal frontiers represented without stimuli that in the concrete perception no longer exist (Glose \& Pustka, 2014). Other methodological problems are attached to the previous: what one wants to investigate is the metalinguistic knowledge of the speakers or the langue, but only the concrete production of the speakers or the parole can be analyzed in cartoons, imitations, surveys on their variational concepts or experiments with voice tests (see Krefeld \& Pustka, 2010, p. 15). And since there is no direct access to the permanent metalinguistic knowledge of the speakers, there is always the risk of answering survey questions in accordance with a supposed social desirability (Postlep, 2012, p. 91). Apart from that, there are differences in linguistic knowledge not only at the individual level, where it is evident (Krefeld \& Pustka, 2010 , p. 15), but also depending on the metalinguistic tradition in certain communities (Sinner, 2014, p. 131). Closely linked to the metalinguistic tradition in a speech community is also the division between self- and heterorepresentations: while metalinguistic concepts about the community itself are defined as self-representations, metalinguistic ideas about other linguistic communities unrelated to the speaker's own would be hetero-representations (Krefeld \& Pustka, 2010, p. 15).

While perceptual variety linguistics intends to include all the variational aspects of the diasystem, it simultaneously approaches, like perceptual dialectology, the linguistic attitudes of speakers, which are part of the theoretical model of perceptual variety linguistics - initially introduced by Pustka (2007) as "culture". However, there is some debate about the position of linguistic attitudes within the scheme: while Krefeld and Pustka (2010, p. 12) separate the attitudes from representations, although they point to a certain relation between them, Postlep (2010a, pp. 55-57) denies dividing concepts into a cognitive and an affective component. Drawing on the ideas of Kabatek (1996, p. 42) and Berruto (2002, p. 353) claiming that a separation between the cognitive structure and the affective component of metalinguistic knowledge is impossible since linguistic attitudes also obtain a conative component that influences linguistic production, Postlep links metalinguistic representations and linguistic attitudes (pp. 55-56). In the present article, a division is maintained between attitudes and cognitive knowledge; the acts of delimiting a certain dialectal zone or naming linguistic features by themselves seem to us simply cognitive even though, like Krefeld and Pustka (2010), we do not deny that they can also have an attitudinal aspect, for example when the linguistic traits lead to positive or negative comments, which we call following Anders (2010) Triggermerkmale (linguistic triggertraits).

\subsection{Methodology}

For the investigation of the Andalusian varieties from the perspective of the perceptual variety linguistics we have created a corpus based on a direct survey that is divided into two parts. ${ }^{12}$ To create the survey we have used methodological elements that have already been applied on other perceptive studies (Postlep, 2010a; Preston

\footnotetext{
12 For more information about the corpus, its production and analysis see Harjus (2018).
} 
(Ed.), 1999; Pustka, 2007; Stoeckle, 2014), since the methodological diversity of perceptual variety linguistics should be treated as complementary (see Krefeld \& Pustka, 2010, p. 15).

The first part of our contribution focuses on the associations that arise between the respondents about the Andalusian varieties and various phonetic features: here, we distinguish between the metalinguistic knowledge, which is demonstrated in mental maps, and the linguistic attitudes of the respondents. This first part of the survey follows the methodical ideas of the perceptual dialectology in asking the speakers to draw regions of different Andalusian speeches on a blank map of Andalusia, to characterize the linguistic zones they highlight and to point out the typical phonic features of each specific variational zone. The latter is the most important aspect in the survey of abstract representations, since it deals with the dimension of specific linguistic knowledge or the inhaltsbezogene Dimension (Anders, 2010, p. 164). This is where the respondents describe the linguistic phenomena that help to identify a specific variety, thus making explicit their idea of salient phenomena of each Andalusian variety. Unlike Postlep (2010b, p. 70), the comments of the speakers are not filtered to extract only the most universal and scientifically valid aspects. Regardless of the extreme complexity of the comments and the greater difficulty in categorizing comments (Anders, 2010, p. 272), this contribution tries to collect strictly emic data ${ }^{13}$ and to do a scientific categorization, which is performed in the analysis through a linguistic classification adapted from Anders (2010, pp. 268-275) and Pustka (2007, p. 231). This classification consists of five different groups in terms of phonic, lexical, and morpho-syntactic aspects as well as descriptive and evaluative expressions that are further subdivided into 24 subgroups. Although in this contribution we are solely interested in the phonic aspects and the descriptive or evaluative expressions of this classification, the challenge of this kind of classification of linguistic associations made by naïve speakers is still that it has to satisfy the demands of an empirical work and, at the same time, should reflect the inexperience of the utterances made by the speakers (Anders, 2010 , p. 267). The last two parts of the survey of abstract representations deal with the subjective difference of the idiolect of the speakers with other Andalusian speakers, the "degree-of-difference", to put it in Niedzielski's and Preston's terms (Niedzielski \& Preston, 2000, p. 77), and with the linguistic attitude of the respondents to the different Andalusian varieties. The last aspect of the questionnaire is similar to what Preston (1999) calls "correct and pleasant" (p. XXXIV). However, instead of giving grades from 1 to 10 to the sympathy and antipathy of the different Andalusian varieties, respondents have to decide on sympathy or antipathy towards the other Andalusian varieties on a binary nominal scale. In this respect, the questionnaire rather resembles Hundt's pilot study (2010, p. 218) on the linguistic consciousness of German speakers. Respondents can choose on a binary scale between sympathy and antipathy from a variety or leave the boxes blank. Likewise, respondents have the option to rate linguistic zones as correct or incorrect.

The second part of the survey is dedicated to the perception. Speakers listened to audio samples and decided from which Andalusian variational area the speakers are and to what social strata they belong. In total, there are 14 different audio samples: twelve of the speakers are from western Andalusia and have different levels of education. The main focus in the collection of these 14 stimuli is on a heterogeneous presence of phonic features of different Andalusian speech communities: in some of the stimuli one can perceive seseo, in other ceceo or heheo ${ }^{14}$ etc. The audio samples last from 20 to 45 seconds. Unlike Postlep (2010a, p. 103), each respondent had to listen to all 14 stimuli, which are made up of spontaneous, rather than practiced, speech acts by Andalusian speakers. We follow Brade's (2010, p. 443) and Williams, Garrett, and Coupland's (1999, p. 346) contributions illuminating that the spontaneous speech of a speaker is much more authentic than some sentences being read. The attention of the respondents is higher because the task becomes more interesting if it is a free talk. Moreover, the difficulty in filiation to a given variety is easier than in a read stimulus (Brade, 2010, p. 445).

Answers of a total of 30 participants ${ }^{15}$ constitute the corpus, which does not seek to achieve sufficient representativeness for a quantitative work, but to offer tendencies for the speech community. This number of speakers approaches the participants in Anders (2010) in each speech community of her study on the German of Saxony and can guarantee the participation of a wide base of Jerezano speakers without exceeding the exploration capacity of a single interviewer, as Stoeckle (2014, p. 102) already admits. The surveys were conducted at different places in Jerez in 2015 and lasted between 40 and 75 minutes per speaker. In order to guarantee diverse social parameters, not only participants of different generations or gender have been interviewed, but also the respondents' level of education was taken into account. Thirteen speakers are college graduates and 11 at least have the ESO (secondary education). Six participants are less educated or illiterate. As the test does not reach an absolute representativeness of the local speech community, we aim at in-

13 "Emic descriptions provide an internal view, with criteria chosen from within the system. They represent to us the view of one familiar with the system and who knows how to function within it himself' (Pike, 1967, p. 38). This means that the respondents themselves place representations of their mental maps and associations of certain Andalusian zones with certain linguistic features in the blank maps of the questionnaire without the interviewer giving any indications. Consequently, the concepts for delimiting the Andalusian variety continuum and the terminology of perceived linguistic phenomena come only from the Jerezano speakers themselves.

${ }_{14}$ The term heheo refers to the aspiration of both Spanish phonems /s/ and / $\theta /$ in an explosive position, such as in [hi] instead of /si/.

15 The interviewees are placed in a purely chronological order from the first survey (A) to the last one $(\gamma)$ : we added three Greek letters to the Latin alphabet because we surpassed the $\mathrm{Z}$ with our participants. 
creasing the representativeness by taking into account extra-linguistic parameters and creating a heterogeneous corpus based on these. Especially the integration of speakers with lower education is new within the research of the perceptual variety linguistics that, in many cases, continues to find its participants exclusively among the young students (see Hundt, 2010; Preston, 1989; Purschke, 2011; Pustka, 2007). Only in a few cases - mainly for a better understanding of the qualitative results - we will quantify the data, which only indicate trends, but absolutely not a representative scientific saturation (see Kuckartz, 2014, p. 84).

\section{ANALYSIS OF JEREZANO SPEAKERS' REPRESENTATIONS AND PERCEPTIONS OF THE PHONIC VARIATION IN ANDALUSIAN SPANISH}

\subsection{Abstract cognitive representations of the phonic variation}

On average, speakers divided the blank maps in the draw-a-map task (Preston, 1999) into 7 different speech zones. The conception of the dialectal area of Andalusia ranges from a minimum of 3 (Figure 1) to a maximum of 16 (Figure 2) different speech areas, which refers to an enormous capacity of differentiation. Most respondents (15) structure the Andalusian dialect area in 6 to 9 zones, as the average of 7.0 mentions reflects. The average of divisions varies slightly according to the extra-linguistic factors. The most determinant factor seems to be age: while the younger generation (6.0) and the more advanced one (6.4) identify a similar number of Andalusian varieties, the intermediate generation highlights an average of 8.7 dialect sectors. This result reaffirms Hansen's (2012) conclusion on the influence of the generational factor on dialectal knowledge: very young speakers emphasize less areas of divergent speech (p. 69).

The way of marking the points is selective (Anders, 2010 , p. 197) in almost all cases (Figures 1 and 2). This means that the respondents have only highlighted areas of Andalusian varieties that can stand out from other areas, but for them the Andalusian dialect does not form a continuum. This is not surprising since, according to Anders (cf. 2010, p. 197), this type of map structure seems to be the most practiced in these types of mental representations of speakers who are not specialized in linguistics. Preston's (1989) data points in the same direction. Contrary to the selective way of mapping, the exhaustive way (Hundt, 2010, p. 180) allows us to infer that the respondent believes that the Andalusian dialectal area is a continuous one. However, only the respondent $\mathrm{N}$ does a comprehensive marking of the map (Figure 3).

Among the respondents who selectively separate the Andalusian varieties, the attention they give to provincial capitals (Cádiz, Seville, Córdoba, Granada, and, to a lesser extent, Málaga and Jaén) is more striking than that for Jerez and the rural areas around the Sierra de Cádiz. Twenty-four of 30 respondents take the main urban nu-
Figure 1: Minimum of selective markings in the map (speaker R): Sevillian, Jerezano, Granadino.

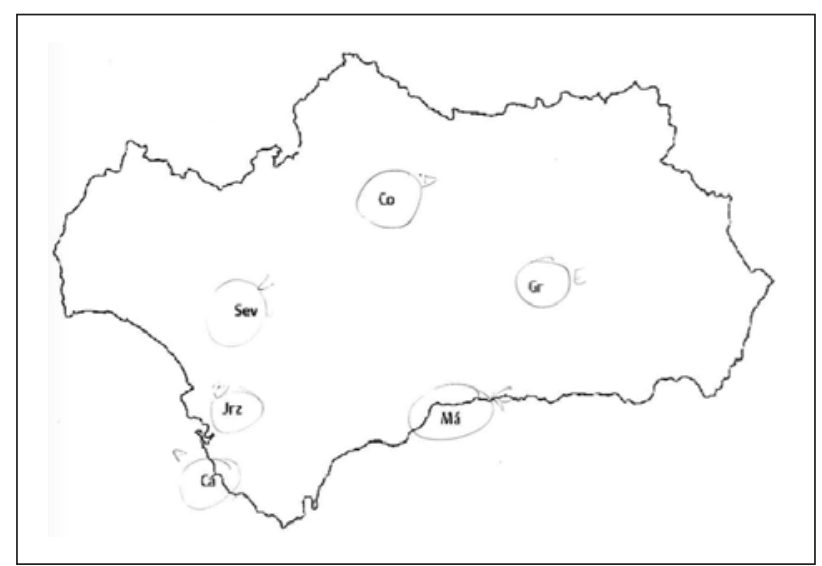

Figure 2: Maximum of selective markings in the map (speaker B): Sevillian, Jerezano, Gaditano, Onubense, Almeriense, Cordoban, Jienense, Malagueño, Lepero, Astigitano, Llanito, Sierra de Cádiz, Sanluqueño, Chipionense.

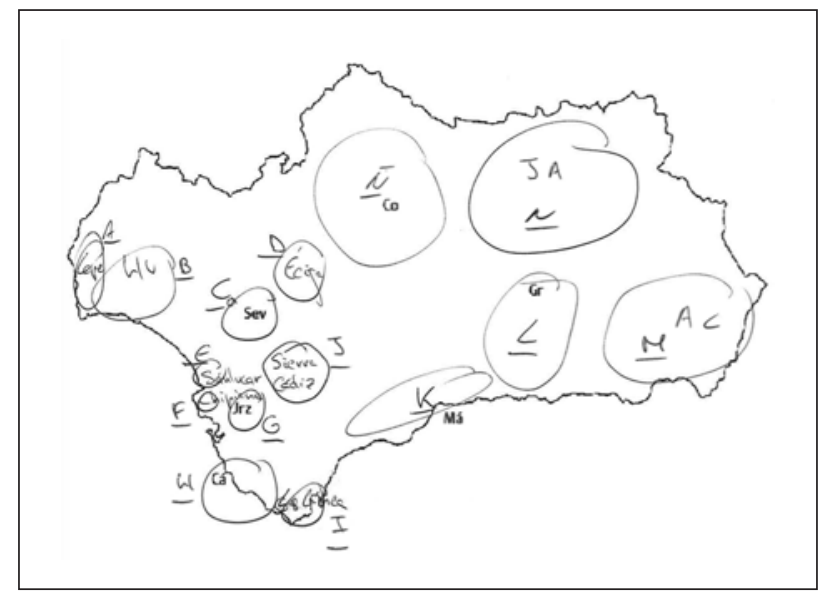

Figure 3: Exhaustive marking in the map (speaker N): Cordobese, Onubense, Sevillian, Rural Sevillian, Gaditano, Sierra de Cádiz, Ubriqueño, Jerezano, Almeriense, Jienense, Grandino, Malageño.

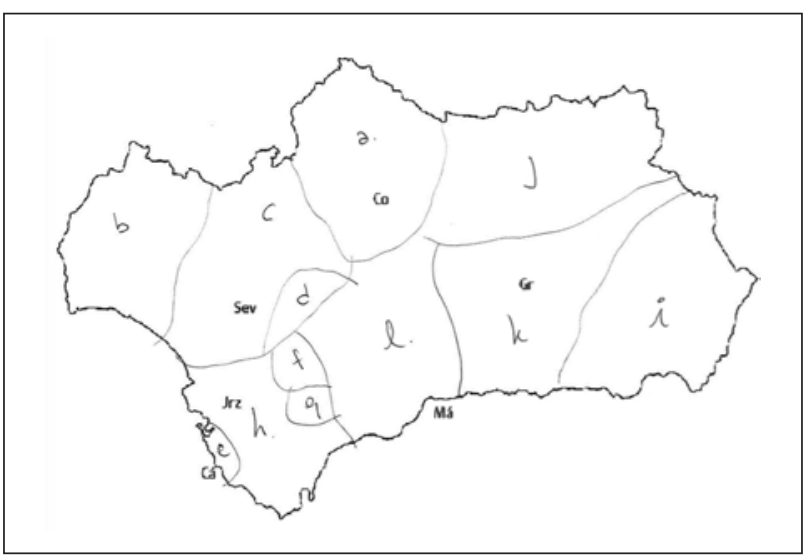


cleus of the Andalusian provinces as a point of reference in the reproduction of the cognitive map. In highlighting provincial capitals, respondents point out the importance they exert within their cognitive space and underline their importance in the Andalusian reality, as already stressed by Bustos Tovar (2013): "En el caso de Andalucía, las áreas dialectales que se aglutinan en torno a ciertos núcleos, tienen una gran estabilidad y no sufren la agresión de variantes focalizadas en otros núcleos" (p. 36). According to Lynch $(1965 / 2001$, p. 62), cities function as an optical point of reference in general. As in the blank map also the names of some cities appear as points of orientation, the attention given to the urban centers of Andalusia by the speakers is not surprising. In his pilot study, Hundt (2010) observes that speakers draw dialect zones around important cities (p. 193). Thus, the spatial categorization of the autonomous community of Andalusia has a strong daily relevance in the distribution of the cognitive space and influences the consciousness of the Andalusian speakers not only on a political-administrative level, but also regarding questions related to the use of language. The political provinces, and especially the capitals of these provinces, constitute the cognitive space of the Andalusian speakers, which is preceded by the categorization of the variational space of the Andalusian varieties, as Christen (2010) also points out for Switzerland.

With regard to the speech communities of Seville, Jerez, and rural Cádiz, which are the ones that are important to this contribution, we must conclude that the two major urban centers of the region are the most prominent in the corpus. Moreover, more than half of the respondents pointed to the Sierra de Cádiz or different villages within this province of Cádiz as a zone of divergent variety to their own. Also, more than a quarter of the respondents name the small speech communities of other regions of Cádiz (e.g., Bajo Guadalquivir with Sanlúcar de Barrameda, etc.). It is noteworthy that some respondents (4) differentiate between the capital of Seville and the speech communities of Sevillian small towns (e.g., Dos Hermanas or Écija), thus indicating an urban/rural division also in the province of Seville. This fact is reflected in the scientific literature on the speech community of Seville (Carbonero Cano, 1982, p. 26). Consequently, the geographical prox- imity of rural localities to their own speech community influences cognitive representations, at least in those of older generations. The younger generation appears to be much more focused on urban points, including those in the east of Andalusia (Granada, Córdoba, Málaga), leaving out of their maps many times the rural areas highlighted by older generations, and focusing on urban points of larger demographics within the autonomous community.

Linguistic features that have frequently been mentioned in scientific linguistic concepts, such as "ceceo" (B) or "seseo" (Y), underline a great metalinguistic knowledge of the respondents. In total, there are 121 divergent linguistic phenomena that have been described by Jerezano speakers. Of these phenomena nearly two thirds are phonic features, which highlights the phonic character of the Andalusian dialectal peculiarities already underlined by Narbona Jiménez, Cano Aguilar, and Velarde-Pérez (2011, p. 165). The phonic features are divided into three subcategories of vowel, consonantal, and prosodic features, which in turn differ in several characteristics. The subcategories of phonological change in consonants (e.g., "ceceo" for respondent B) and vowels (e.g., "alargamiento vocálico" for respondent H) together account for half of all phonic-related mentions. Apart from these subgroups, a further three account for a quarter of all references: consonant quality, single consonant, and negative evaluative expressions.

For respondents, the phonic elements are also the most prominent linguistic traits of their own variety. Within these, the salient phonological phenomenon of Jerez is ceceo, a feature that is very abundant in linguistic characterizations, as for example in "cecean" (Q), "ceceo" (B) or "s=z" $(\gamma)$. Within the descriptions of ceceo there are no extra-linguistic differences, since independently of the educational level, gender, or age, the phonic feature stands out and all describe it with a specific linguistic term, as in "ceceo" $(\mathrm{O})$ or "cecean" $(\mathrm{N})$, or with a more plastic vision, as for example in "cambian la $s$ por la $c$; ejemplo caza (casa)" (D), in "sustituyen la letra $s$ por la $z$ " $(\mathrm{P})$, or in "cambian la $s$ por la $z$ " $(\tilde{\mathrm{N}})$. In addition, some indicate that typical of their own speech community are the relaxed pronunciations of the $/ \mathrm{tg} /$ and $/ \mathrm{x} /$ : "aspiración de la $\mathrm{j} \rightarrow \mathrm{h}$ " (X), "sh" (O), "musho" (ß) o "koshe" (Z) (Table 1).

Table 1: Comments about Jerezano linguistic features made by Jerezano speakers. Letters in parenthesis refer to the speakers.

\begin{tabular}{|c|c|c|}
\hline \multicolumn{3}{|c|}{ Jerez de la Frontera } \\
\hline Phonic features & consonants & 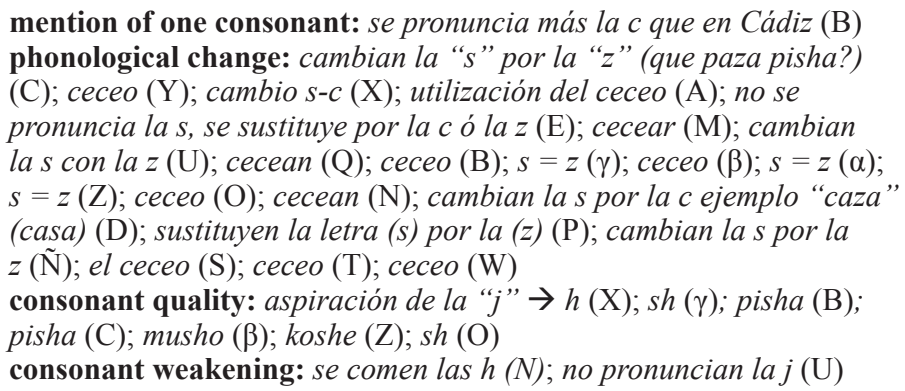 \\
\hline Descriptive expressions & descriptive & self-referential: porque yo soy jerezana $(\mathrm{R})$ \\
\hline
\end{tabular}


The variety of Seville seems to be different from that of Jerez: according to the speakers, in the Sevillian variety there is a phonological neutralization in favor of seseo instead of ceceo. This linguistic feature is, with 16 comments, salient for the respondents. Although men indicate the phonic feature more frequently, the great extra-linguistic difference with respect to the naming of seseo for Seville is the educational level of the speakers. While low-educated speakers do not refer to phenomena by virtue of the technical term, but using the actual sound [s], as in "s" $(\mathrm{O})$ or "hablan con s" $(\mathrm{G})$, high-educated people often employ the appropriate linguistic term, for example in "sesear" (Q), "seseo" (X), or "sesean" (N). A certain prestige of the Sevillian variety in the opinion of the respondents is only partially noticed in the comments made. Although Seville's variety is defined as "muy fino" (E) or even in a self-referential manner as "el habla es más fina" $(\mathrm{V})$, there are also negative references indicating that the variety is seen as "chulita" $(\mathrm{Z})$ (Table 2).

Unlike the capital of Seville and the own speech community, the participants frequently value the rural area of the Sierra de Cádiz. These comments are always negative, as in "demasiado vulgar" $(\alpha)$, or ironic, as in "refinado jejeje" $(Z)$, and usually made by college students. Aside from prosodic signs, as in "hablan cantando" (D) or "melodía al hablar" (G), the notes on the use of $[\mathrm{h}]$ instead of /s/ abound, for example "pronuncian s como $\mathrm{j}$ (Puerto Jerrano)" $(\mathrm{N})$, "s $=\mathrm{h}$ " $(\gamma)$ or "hablan mucho con la j y z (Jervejita)" (T). There are participants who emphasize the сесеo of the speakers of the rural area and there are others that emphasize the heheo, but only a few use in their descriptions the appropriate scientific term, "ceceo" $(B)$ or "heheo" $(\beta)$ (Table 3).

Therefore, Jerez and the rural areas of the western provinces of Cádiz and Seville, although separated by isoglosses put by the participants, constitute a ceceante zone. This naïve view separates a seseante area, linked to the speech communities of the urban centers with political-administrative functions at the provincial level (Málaga, capital of Seville, capital of Cádiz), from another clearly rural ceceante area plus their own speech community. They think that they have more phonic features in common with rural areas, such as ceceo, use of the [J] fricative and aspiration of the $/ \mathrm{x} /$. This difference between the prominent spaces is also manifested in the degree of difference that the speakers themselves establish between Seville, Jerez, and the rural areas of Cádiz. While the eastern areas of Andalusia (e.g., Granada or Almería) are rated at an average of 4.0, participants split the western part into two different areas: a part is made up of the cit-

Table 2: Comments about Sevillian linguistic features made by Jerezano speakers. Letters in parenthesis refer to the speakers.

\begin{tabular}{|c|c|c|}
\hline \multicolumn{3}{|r|}{ Seville City } \\
\hline \multirow[t]{2}{*}{ Phonic features } & consonants & 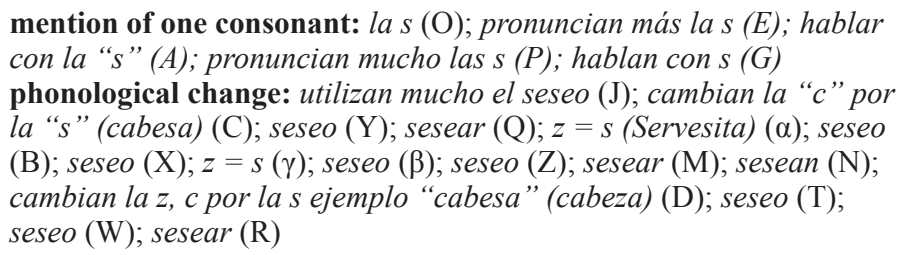 \\
\hline & prosodic features & intonation: entonan pronunciadamente $(\mathrm{P})$ \\
\hline \multirow[t]{2}{*}{ Descriptive expressions } & descriptive & reference to a famous person: Sergio Ramos (Z) \\
\hline & rating & $\begin{array}{l}\text { negative: chulito }(\mathrm{Z}) \\
\text { positive: el habla es más fino }(\mathrm{V}) \text {; hablan muy fino }(\mathrm{E})\end{array}$ \\
\hline
\end{tabular}

Table 3: Comments about rural Gaditano linguistic features made by Jerezano speakers. Letters in parenthesis refer to the speakers.

\begin{tabular}{|c|c|c|}
\hline \multicolumn{3}{|c|}{ Rural Cádiz (Sierra de Cádiz) } \\
\hline \multirow[t]{2}{*}{ Phonic features } & consonants & 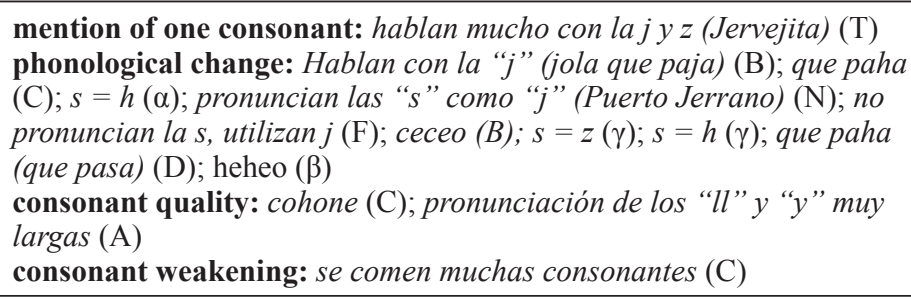 \\
\hline & prosodic features & $\begin{array}{l}\text { intonation: hablan cantando }(\mathrm{D}) \text {; melodía al hablar }(\mathrm{G}) \\
\text { syllable: Aspiración de comienzos y finales de palabra }(\mathrm{D})\end{array}$ \\
\hline \multirow[t]{2}{*}{ Descriptive expressions } & descriptive & comparison with non-Andalusian dialects: acento mexicano (F) \\
\hline & rating & negative: demasiado vulgar $(\alpha)$; refinado jejeje $(\mathrm{Z})$; gracioso $(\mathrm{Z})$; rural $(\beta)$ \\
\hline
\end{tabular}


ies of Seville and Málaga, adding some of the southeast regions of the province of Huelva. The zones in this part receive the placement of "more different than similar" with an average of more than 2.9. Finally, they point to the nearest part of Jerez, some rural areas of the province of Seville and the rural regions of the province of Cádiz including the capital. For Jerez respondents, these areas are "similar" (1.8-2.4) to their own speech community. On the one hand, middle-aged speakers perceive the rural areas very close to their own and establish a greater distance between their own speech community and those of Seville and Cádiz. On the other hand, educated and younger speaker see a slightly approach to Cádiz's variety, but not to the urban variety of Seville. Gender differences offer an image similar to the generational ones, manifesting a closer proximity to the ceceante zones (Sierra de Cádiz) and greater distance to the seseante regions (Cádiz, Seville) by the women surveyed, but a greater proximity of the men to the regions with a salient seseo.

With regard to the linguistic attitude, it is necessary to mention that Jerezano speakers evaluate very positively the sympathy of the closer western Andalusian varieties. Along with the variety of Jerez, the rural ones of western Andalusia are qualified as being sympathetic. However, the urban variety of Seville is, according to the speakers, also rather sympathetic than unfriendly. The only sociolinguistic differences are in the handling of the variety of urban Seville, whose habla seems to attract the sympathy of the most prepared men and younger generations. The second generation, the women and averagely-educated respondents show more antipathy towards the Sevillian variety. However, only in the case of women does antipathy outweigh sympathy. This observation underscores Kontra's (2002) statements about divided subjective opinions of speakers who live outside provincial capitals towards major urban centers. Regarding the accuracy of the Andalusian varieties, it should be noted that the rural points of the province of Cádiz and some of the province of Seville receive the worst appraisal by the Jerezano speakers, a fact that reflects a possible stigma of the rural Andalusian varieties. The capital of Cádiz and Jerez itself receive slightly more positive than negative evaluations. The vast majority of participants considers the variety of the urban speech community of Seville as a bit more correct than incorrect. This fact shows a certain prestige of the Sevillian habla for the Jerezano speakers on the one hand. On the other, however, more than a quarter considers the variety of Seville to be incorrect.

\subsection{Concrete perceptions of the phonic variation}

The Jerezano speakers have a great metalinguistic knowledge, which is also demonstrated in the part of the concrete perceptions. Although second-generation participants and those with an average level of education appear to be the respondents who correctly track the localization of voice sample tests rather than the rest, we must refute the hypothesis that, compared to young people, older people locate other speakers better. While perceptual studies in anglophone language communities have demonstrated the validity of this hypothesis (Torgersen, 2012, p. 91), it is important to emphasize that young people also have a high linguistic consciousness in the local speech community being examined here. It is striking that there are also no major differences in the accuracy of the perception of the level of education of the participants in the corpus, although it seems certain that lower educated people use less adequate linguistic terms than those with a college degree or have an average level of education.

The linguistic features perceived in greater numbers have been those of the phonological neutralization of $/ \mathrm{s} /$ and $/ \theta /$, associated with divergent dialectal zones in western Andalusia. The defonologización in favor of ceceo is always located in a self-referential way, that is, within the own speech community of Jerez, or within the rural varieties of Cádiz: therefore, the phonic feature of ceceo is associated mainly with the own speech of the respondents or with the near varieties of the rural region, highlighted in the degree of difference by their closeness. Many times the separation of both areas in the concrete perception, in the part of the simple representations still well distinguished, is very complicated for the Jerezano speakers: if they perceive a ceceante speaker they doubt if it is of their own speech community or from the rural areas of the province of Cádiz, or even from the rural area of the province of Seville, for example in the stimuli (a), (c), (f), $(\mathrm{g}),(\mathrm{l})$, and $(\mathrm{m})$. This result strengthens, on the one hand, Ropero Núñez's (2001) conclusion for the metalinguistic consciousness of Sevillian speakers that ceceo is located more in the rural speech communities of Andalusia: "El ceceo en cambio todavía se suele asociar con el habla rural" (p. 39). But the Jerezano speakers associate a perceived сесеo of a stimulus not only with the varieties of the rural areas of Cádiz and Seville, but also with their own variety. This fact, on the other hand, emphasizes a remarkable rurbanity of the speech community of Jerez (Harjus, 2018), since, unlike in the part of the representations, the respondents do not perceive any difference between both dialect zones.

On the contrary, the phonological neutralization in favor of seseo, as perceived in stimuli (b), (d), (e), or (k), is never associated with the speech community of Jerez, but always with the varieties of the provincial capitals of western Andalusia, especially with those of Seville and Cádiz, and, although rarely, with the speech community of Málaga and the zone of the Cordoban variety in eastern Andalusia. Therefore, the respondents divide the western Andalusian communicative space into two zones: the varieties of the large urban conglomerates, Seville, Cádiz, and Málaga, are associated with the phonic feature of seseo, while the ones spoken in the rural areas of the provinces of Cádiz and Seville along with the variety of Jerez are linked to the phenomenon of ceceo.

Therefore, according to the conscience of the respondents from Jerez, there is a multidimensionality of linguistic communication in the dialectal space of western Andalusia, since they distinguish between an urban and a rural 
area. Piredda (2014) analyzes the same phenomenon in a study on the perception of Sardinian speakers, where she summarizes that their respondents cannot exactly locate the stimulus but can always distinguish perfectly between Sardinian rural and urban areas (pp. 75-79). In contrast to Sardinian speakers, who do not mention specific linguistic markers (Piredda, 2014, p. 79), the Andalusian participants of this contribution justify their locations in the urban area (capitals of Seville, Cádiz, Málaga, or Córdoba) or rural areas of Cádiz or Seville, including its own speech community, with the distinctive features of seseo or ceceo respectively. Above all, the absolute and total rejection of seseo for the local speech community indicates, as in the part of the representations, that this phonic feature is perceived as a deviation in the Jerezano variety. The fact that Boughton (2010) indicates that respondents in Paris note small linguistic differences in Alsace-Lorraine variety, but do not know how to delimit the geographical origin of perceived speakers (p. 107), underlines the enormous metalinguistic knowledge that Jerezano speakers have about their linguistic variety in general, and of the phonological neutralization of the /s/ and the $/ \theta /$ in particular, since they can distinguish perfectly between these salient linguistic features.

With regard to the perception of social factors, it should be noted that seseo, as a phenomenon perceived from a stimulus, leads the speakers - much more frequently than it is the case with a salient ceceo-to locate the stimuli speakers within a higher educational level. On the contrary, ceceo perceived in a voice sample is often associated with the variety of speakers with a low level of education. This result seems to confirm, for the Jerezano speech community, Ropero Núñez's ideas about the Sevillian one: that seseo has more prestige than ceceo and it is highly socially accepted throughout western Andalusia (2001, p. 39).

Within the Jerez speech community, seseo also seems to be prototypical for more cultured speakers, and with this it can be concluded that it is also highly accepted, since there is a correlation between the assignment of a certain social character and the acceptance of the perceived linguistic variable (see Krefeld, 2010, p. 171). The results of linguistic attitudes about the variety of urban Seville demonstrate this as well. However, it must be reiterated that, despite the supposedly higher social status of seseo versus ceceo, this phonic feature is never associated with the local speech community itself. Seseo, which is accepted regardless, may not be part of the local variety, since it cannot be from there: "no puede ser de aquí" $(\alpha)$. Therefore a stimulus with the salient phonic phenomenon of seseo is never located within the Jerezano speech community.

In addition, seseo is not always associated with speakers of more educated levels. While only three respondents believe that the speaker from stimulus (d) has a college degree, almost a third of all respondents (9) perceive a speaker with little education. And even among the social categorizations of the speakers of stimuli (b), (e), and (k), which are mostly characterized as college students, there are up to one sixth of the perceptions of speakers without secondary education. Not only does this fact demonstrate that the individual qualification of phonic features can vary considerably (Anders, 2010, p. 354), but also that the use of seseo is not always prestigious.

Then, it is necessary to reject an alleged stigmatization of ceceo in Jerez, often associated to it in other Andalusian speech communities, such as Seville (Ropero Núñez, 2001) or Granada (Moya Corral \& García Wiedemann, 1995): the social perceptions of the speakers of the stimuli (c), (f), and (m) as speakers with the highest level of education clearly demonstrate that ceceo forms part of the prestigious phonic forms of the Jerezano variety. However, it is striking that among low-educated respondents almost nobody recognizes a high-cultured speaker: uneducated speakers do not associate a high level of education with a salient ceceo. On the contrary, the rest of the respondents does not hesitate to locate the ceceo speakers between the higher educational levels. And although it is not possible to rule out the possibility that certain high social categorizations of the ceceante stimuli $(\mathrm{c}, \mathrm{f}, \mathrm{m})$ and the low social caracterization of the seseante stimulus (d) can be motivated by protection of the own variety itself, as Brade (2010) supposes for self-consciousness of Caribbean varieties (p. 452), this result underscores the persistence of the old stereotype of the use of ceceo among less educated speakers. Yet, among the higher educated Jerezano speakers, this stereotype seems to be antiquated and the social perceptions on high educational levels show the concealed prestige that ceceo receives even among the most educated speakers of the local speech community.

Finally, it is indispensable to verify the importance of the content of a stimulus and the narration style of a speaker in the voice sample for the social perception. Brade (2010, p. 445) already emphasizes the problem that respondents can turn their attention in unread stimuli to the style of the narrative: this way we can explain the positive comments about the speaker of stimulus (b), who speaks fluently ("habla fluido"; N), the positive ones about the stimulus (m), "por la forma del comentario" $(\mathrm{F})$, or the negative ones about the speaker of the voice sample which is described as relatively uncultivated by the way of expressing itself ("por la forma de expresarse"; O). Additionally, some respondents turn to the content of what is expressed in the stimuli. As already mentioned in the methodology part, the decision to use stimuli taken from free conversations has the advantage of obtaining a maximum of spontaneity and authenticity, but they invite the speaker to look at the content: "[Es] liegt die Annahme nahe, dass der Inhalt des Textes besonders großen Einfluss auf die Bewertung nimmt" (Brade, 2010, p. 443). In the part of the concrete perceptions, only some participants express openly that they base their social categorization of the speaker in the content narrated in the voice sample, as for example in "contenido básico" (N) for the stimulus (i) or "no tiene inquietudes" (Q) for the stimulus (g). Nevertheless, it is evident that often the combination of the narrative style 
and the content expressed in the stimulus forms the main basis for the social categorization of the perceived speaker: in this way, the perceived salient linguistic features of the speakers of the stimuli (a) and (c), mainly ceceo and the fricativization of the affricate, are the same. However, once respondents identify a low-educated speaker in stimulus (a), they recognize a speaker with a university grant in stimuli (c). This result demonstrates the utmost importance of what a speaker expresses and the least importance of which salient variables they realize: therefore, it can be emphasized as a result of this perceptive inquiry that the content of a statement is more important in the social categorization of a speaker than the realization of certain linguistic features. Therefore, the ceceante realization is not at all a phonological feature linked to the lower social strata within the Jerezano speech community.

\section{DISCUSSION AND CONCLUSIONS: THE SALIENCE OF CECEO AND SESEO IN JEREZANO SPEAKERS' CONCEPTS AND PERCEPTIONS}

The respondents from Jerez separate different Andalusian zones into the categories of representation and concrete perception. These categories are based on political boundaries or urban areas in certain mental maps, thus confirming the idea that political-administrative or cultural aspects are more important than merely the linguistic ones (Kehrein, Lameli, \& Purschke, 2010, p. 379). However, linguistic features also help speakers to locate divergent varieties, not only on the part of the representations but also on the part of the perceptions. It is necessary to emphasize that the distribution of dialect zones in the part of the representations is more numerous than in the part of concrete perceptions and that the segmentation of the mental maps without stimulus is more detailed. Nevertheless, the respondents demonstrate their great metalinguistic knowledge also in concrete perceptions, which rejects Woehrling \& Boula de Mareüil's (2006) argument that the linguistic knowledge of speakers is only a pseudo-linguistic knowledge. In contrast to other studies in which, independently of the linguistic field of research, the respondents' performance in the simple representation was better compared to the true perception (Glose \& Pustka, 2014, p. 96), the performance of the Jerezano speakers did not fall considerably in the part of the concrete perception. All speakers, then, demonstrate a comparable tendency towards discrimination in both the conceptual and perceptual sides, as there are no major differences with respect to age, gender, or level of education.

In certain surveys it can be seen that the speakers' linguistic knowledge is often based on intuitive knowledge (Kabatek, 1996, p. 40), especially if specific motivations are missing in simple representations. But these gaps are rarely found in our corpus. This fact illuminates that talking about linguistic variation is not unusual in the local speech community and is part of everyday Andalusian communication. Accurate results of the corpus, both in representation and in perception, underline this idea and show a good metalinguistic knowledge of the speakers, which Postlep (2010a) also ascribe to the Aragonese speakers (p. 222). In describing the phonic features, many respondents from Jerez use linguistic terms such as seseo, ceceo, or even heheo. The use of this technical language by the Jerezano speakers contradicts Spiekermann's (2010) pessimistic hypothesis of naïve speakers that are not specialists in linguistics not knowing how to express their metalinguistic ideas (p. 222).

The reciprocal relationship between representation and perception is manifested in the location of various voice samples. The location of the lenition of the Spanish affricate can be related to the representation and also to the perception: the feature in the representations as well as the perception is associated with the zone of Cádiz capital (i), the rural areas of Cádiz (a, c, m), and that of Jerez (a, c, i, l, m). Therefore, the sound [ $]$ ] has a high prototypicality for the modalities of these areas and is almost never - the rural area of Seville (c) is the only exception-associated with other Andalusian varieties. On the contrary, intonation is mentioned from time to time in the part of representations to distinguish different rural varieties nearby Jerez, but during the concrete perception the suprasegmental phonic feature serves almost only to emphasize non-Andalusian Spanish modalities (j). The associations with the phonetic feature of the heheo are very interesting: in the representations, the respondents highlight the phenomenon for the modalities of the rural areas of western Andalusia, especially for those of Cádiz and those of Huelva. However, the locations of partially heheante stimuli $(\mathrm{g}, \mathrm{i}, \mathrm{n})$ are mostly made in a self-referential way in the perception part, that is, within the speech community of Jerez itself. Consequently, there is a lack of differentiation between the rural varieties of Cádiz and the Jerez modality in the perceptive part, whereby both modalities, which were still well distinguished in the part of the mere cognitive representations, are homogenized. In any case, the relative proximity between the linguistic variety of Jerez and those of the more rural areas of the province of Cadiz is already evident in the salient features highlighted in the representational part and in the degree of difference. However, the vast majority separates the speech community itself from rural areas in the part of the representation, but is unable to maintain this geographical division in true perception. This conclusion indicates that the Jerezano speakers still have a very rigid structure of linguistic stereotypes when confronted to the rural Cádiz varieties that de facto no longer seems to exist in reality. The same phenomenon appears in the dialectal continuum of Saxony (cf. Anders, 2010, p. 353).

The most important result of the analysis is that the respondents maintain the separation of ceceante and seseante areas not only in the representations, but also in concrete perceptions. In theoretical concepts, seseo is a prototypical feature for the varieties of the capitals of Seville and Cádiz. This phonological feature distances these 
urban varieties from the speech community of Jerez, which along with the rural varieties of Cádiz, is characterized by the prototypical feature of ceceo. These divisions between the seseante speakers of urban areas and the rural areas plus Jerez, which are linked to the linguistic phenomena of сесеo, are maintained in the part of perceptions. Therefore, while ceceo is associated in both parts of the corpus with the own speech community or the most rural, seseo is never located within the Jerez or rural Cadiz varieties. It is clear that the speakers' ideas of a clear dialectal separation between a seseante and more urban Andalusian area and another ceceante and rural western Andalusian zone can be based on certain social stereotypes rooted within the speech community, as Boughton (2010) points out for perceptions of Parisian speakers about European French (p. 199). Nevertheless, the results reinforce and reflect at the same time the ancient conclusions about the dialect areas in Andalusia proposed in the ALEA (Alvar et al., 1973). In addition to that, the data obtained through the analysis of the corpus clearly indicate that, for the Jerezano speakers themselves, seseo is not a part of the linguistic features of the Jerezano speech community, confirming the results of the descriptive investigations of phonetic and phonological studies conducted on the local variety by García-Amaya (2008) and Harjus (2018). Consequently, it has been shown that the existence of a supposedly Sevillian regional standard for the Jerezano speech community, at least if it is mainly based on the use of seseo (VillenaPonsoda, 2008), has not reached the consciousness of local speakers. The results thus strengthen the idea that within the local speech community ceceo enjoys a wide prestige. It is therefore agreed with Davies (2010) that the linguist should include the metalinguistic knowledge of the speakers themselves more frequently (p. 387). As enhanced in the theoretical part, considering naïve speakers' metalinguistic knowledge is not only important in affirmative contexts as in this contribution, in which descriptive data are confirmed, but also in situations in which they appear to refute certain conclusions scientifically obtained by the linguist (see Kabatek, 1996, p. 44).

The maintenance of the antagonistic subzones of seseo and сесео in the perceptional part emphasizes the importance of these salient features for the Jerezano speakers' conscience and assigns them the state of prototypicality for the western Andalusian varieties and the Jerez variety respectively. The prototypicality of these phenomena of phonological neutralization is so distinctive that when perceiving a $/ \mathrm{s} /$ in the discourse of a voice sample, the respondents categorically discard the possibility that the speaker listened to may be from Jerez, which indicates that the naïve conclusions of de la Plata (1993, p. 18) about the use of seseo in the speech community are not far from the linguistic awareness demonstrated in the corpus. The data of the corpus, then, strengthens the division between the self and the other, indicating a "Wir-Gefühl" (Krefeld 2010, p. 168), that is to say a maximum identification by virtue of the ceceo feature.
The results of the corpus also clearly indicate that the saliency of certain linguistic features is not always linked to the reduction of the phenomena (Lenz, 2010, p. 106). In particular, the use of ceceo even in distant communicative situations in the speech community of Jerez (cf. Harjus, 2018) demonstrates - along with the prototypicality in the representations and in the perceptions of this contribution - that this phonological feature is an identifying marker (Lenz, 2010, p. 107). Already Auer and Hinskens (1996) demonstrate a linguistic behavior similar to that analyzed for the Jerezano speakers for the Saxon speech community (p. 163). Therefore, the results of this work contradict the ideas of Schirmunski (1928-1929, p. 166) and Mattheier (1996, p. 41) that there is a strong correlation between a salient phenomenon and its reduction. On the contrary, it strengthens Lenz's (2010) thesis that it is not possible to justify an equation of the saliency of certain linguistic features and a diminished realization of it: "Gleichsetzung von Salienz und Abbau einer Variant [ist] nicht per se gerechtfertigt" (p. 108).

With respect to linguistic attitudes, it is conspicuous that linguistic forms of urbanized centers, especially Seville and Málaga, receive high numbers of accuracy, and the fewer speakers a speech community have-such as the rural areas of Cádiz - the more incorrect the Jerezano speakers evaluate them. This evaluation appears to be linked to the larger population of certain dialectal areas, rather than to the prototypical features: seseo is evaluated positively for western capitals and ceceo is evaluated negatively for rural areas, including Jerez. Interestingly, this aspect is repeated in the true perception, where supposedly speakers from seseante area stimuli are evaluated positively and with comments like "claro", "fino", "muy fino" or "habla correctamente". But the detailed analysis shows that not all linguistic varieties linked to the salient feature of seseo are evaluated positively: both for attitudes and true perception there is a great difference between the accuracy of the Sevillian variety and the urban variety of Cádiz, although both have the salient feature of seseo. As in the Catalan-Aragonese continuum in northern Spain (Postlep, 2010b, p. 81), the metalinguistic consciousness of Jerezano speakers appears to be based on a center-periphery model, in which the accuracy of certain varieties rises with increasing political or cultural relevance and the larger population of the urban area.

The ambiguity about the phonological feature of seseo, absent in Jerez's own linguistic variety according to its speakers, is also demonstrated in the comments about seseo speakers in perception. A seseante speaker is described as "fino", which implies that he is urbane, polite, and well educated, but at the same time as "artificial", implying that the speech is unnatural and false, or as "forzado" implying that it is not natural and unspontaneous. Therefore, respondents consider seseo both in the part of the representations and in the perceptions as correct, but alien to the local variety itself. Narbona Jiménez et al. (2011) already mention a certain relationship between an artificial pronunciation and its perception by the speakers: "Los andaluces captan muy bien cuándo es artificiosa (habla finolis)" (p. 327). Ropero 
Núñez and Pérez Santamaría (1998) indicate in the same direction when mentioning statements of speakers from a small village near Jerez:

El andaluz me gusta. Una persona cuando se va a un sitio y vuelve, viene "fina". Eso no me gusta. ...Cuando yo me fijo en otra persona hablando y voy a mi casa y hablo asín [sic], me dice mi madre: no hables asín [sic]” (p. 20).

Therefore, it has been proved that within the local speech community speaking with seseo does not mean that a speaker employs correct pronunciation, but indicates a total removal from the local norm. And especially the higher social recognition of the stimuli (c), (f), and (m), with the linguistic feature of ceceo, in correlation with the expressed content indicates perfectly that ceceo continues having high prestige within the speech community of Jerez. We must therefore emphasize Postlep's (2010b) conclusion on the Catalan-Aragonese speech community enhancing that assumptions about possible linguistic changes in certain regions should be avoided if they are based on generalized opinions on certain allegedly discredited linguistic features (p. 82).

\section{REFERENCES}

Alfaraz, G. G. (2002). Miami Cuban perceptions of varieties of Spanish. In D. Long \& D. R. Preston (Eds.), Handbook of perceptual dialectology: Volume 2 (pp. 1-12). Amsterdam: John Benjamins. https://doi.org/10.1075/z.hpd2.06alf

Alvar, M., Llorente, A., \& Salvador, G. (1973). Atlas lingüistico y etnográfico de Andalucía: Fonética y fonología. Morfología. Sintaxis. Granada: CSIC (vol. 6).

Anders, C. (2010). Wahrnehmungsdialektologie - Das Obersächsische im Alltagsverständnis von Laien. Berlin: De Gruyter. https://doi.org/10.1515/9783110221343

Auer, P., \& Hinskens, F. (1996). The convergence and divergence of dialects in Europe. New and not so new developments in an old area. In P. Auer, F. Hinskens, \& K. J. Mattheier (Eds.), Konvergenz und Divergenz von Dialekten in Europa (pp. 2-30). Tübingen: Niemeyer.

Berruto, G. (2002). Sul significato della dialettologia percettiva per la lingüistica e la sociolinguistica. In M. Cini \& R. Regis (Eds.), Che cosa ne pensa oggi Chiaffredo Roux? Percosi della dialettologia percezionale all'alba del nuovo millennio (pp. 341360). Alessandria: dell'Orso.

Boomershine, A. (2006). Perceiving and processing dialectal variation in Spanish: An exemplar theory approach. In T. L. Face \& C. A. Klee (Eds.), Selected Proceedings of the 8th Hispanic Linguistics Symposium (pp. 58-72). Somerville, MA: Cascadilla Proceedings Project.

Boughton, Z. (2010). Perzeption und Evaluation der Variation im gesprochenen Französisch. In T. Krefeld \& E. Pustka (Eds.), Perzeptive Varietätenlinguistik (pp. 103-122). Frankfurt a. M.: Peter Lang.

Brade, J. (2010). (Sprach-)Einstellungen in Mexiko. Ergebnisse einer empirischen Untersuchung. In T. Krefeld \& E. Pustka (Eds.), Perzeptive Varietätenlinguistik (pp. 431-455). Frankfurt a. M.: Peter Lang.

Bustos Tovar, J. J. de (2013). Las hablas andaluzas en el mosaico de variedades del español. In A. Narbona Jiménez (Ed.), Conciencia y valoración del habla andaluza (pp. 17-43). Sevilla: Universidad Internacional de Andalucía.
Carbonero Cano, P. (1982). El habla de Sevilla. Sevilla: Ayuntamiento de Sevilla.

Carbonero Cano, P. (1985) (2nd ed.). Norma estándar y actitud sociolingüística. In P. Carbonero Cano \& V. Lamíquiz (Eds.), Sociolingüistica andaluza 1. Metodología y estudios (pp. 141-150). Sevilla: Universidad de Sevilla.

Carbonero Cano, P. (2003). Estudios de sociolingüística andaluza. Sevilla: Secretariado de Publicaciones de la Universidad de Sevilla.

Carbonero Cano, P., Alvarez Cubero, J. L., Casas Gómez, J., \& Gutiérrez Sánchez, I. M. (1992). El habla de Jerez: Estudio sociolingüístico. Jerez de la Frontera: Biblioteca de Urbanismo y Cultura.

Chomsky, N. (1980). Rules and representations. New York: Columbia University Press.

Christen, H. (2010). Was Dialektbezeichnungen und Dialektattribuierungen über alltagsweltiche Konzeptualisierungen sprachlicher Heterogenität verraten. In C. A. Anders, M. Hundt, \& A. Lasch (Eds.), „Perceptual Dialectology“: Neue Wege der Dialektologie (pp. 269-290). Berlin: De Gruyter.

Congosto Martín, Y. (2009). Sobre el desarrollo de la dialectología en España. Revista Internacional de Lingüistica Iberoamericana, 7(1), 63-112.

Davies, W. (2010). Die Rolle (laien-)linguistischer Mythen bei der Reproduktion (sozio-)linguistischer Normen. In C. A. Anders, M. Hundt, \& A. Lasch (Eds.), „Perceptual Dialectology“: Neue Wege der Dialektologie (pp. 387-408). Berlin: De Gruyter.

Díaz-Campos, M., \& Navarro-Galisteo, I. (2009). Perceptual categorization of dialect variation in Spanish. In J. Colletine, M. García, B. Lafford, \& F. Marcos Marín (Eds.), Selected Proceedings of the 11th Hispanic Linguistic Symposium (pp. 179195). Somerville, MA: Cascadilla Proceedings Project.

Díaz Salgado, L. C. (2002). Creencias y actitudes sobre usos fónicos "innovadores" del andaluz en los periodistas sevillanos de Canal Sur Televisión. In Tonos Digital, 3. http://hdl.handle. net/10201/40515

Erdösová, Z. (2011). El español de México en los ojos de sus hablantes. Un estudio desde la Sociolingüística y la Dialectología Perceptiva. Lengua y voz, 1(1), 57-81.

García-Amaya, L. J. (2008). Variable norms in the production of the $/ \theta /$ in Jerez de la Frontera, Spain. In J. F. Siegel, T. C. Nagle, A. Lorente-Napole, \& J. Auger (Eds.), Gender in language: Classic questions, new contexts (pp. 49-71). Bloomington, IN: IULC Publications.

Gauger, H.-M. (1976). Sprachbewußtsein und Sprachwissenschaft. München: Piper.

Glose, E., \& Pustka, E. (2014). Kreolisch und Französisch auf Les Saintes (Guadeloupe): Repräsentationen - Produktionen - Perzeptionen. In T. Krefeld, \& E. Pustka (Eds.), Perzeptive Linguistik: Phonetik, Semantik, Varietäten (pp. 87-116). Stuttgart: Franz Steiner.

Grootaers, W. (1999 [1964]). The discussion surrounding the subjective boundaries of dialects. In Preston, D. R. (Ed.), Handbook of perceptual dialectology: Volume 1 (pp. 115-130). Amsterdam: John Benjamins. https://doi.org/10.1075/z.hpd1.15gro

Guzmán, M. (2010). Das Spanische in der Karibik: Selbst- und Fremdwahrnehmung. In T. Krefeld \& E. Pustka (Eds.), Perzeptive Varietätenlinguistik (pp. 31-60). Frankfurt a. M.: Peter Lang.

Hansen, S. (2012): Dialektalität, Dialektwissen und Hyperdialektalität aus soziolinguistischer Perspektive. In S. Hansen, C. Schwarz, P. Stoeckle, \& T. Streck (Eds.), Dialectological and folk dialectological concepts of space: Current methods and perspectives in sociolinguistic research on dialect change (pp. 48-74). Berlin: De Gruyter. https://doi.org/10.1515/9783110229127.48

Harjus, J. (2016): Sociofonética andaluza y lingüistica perceptiva de la variación: El español hablado en Jerez de la Frontera. Unpublished $\mathrm{PhD}$ thesis, University of Mainz-Germersheim.

Harjus, J. (2017). La visibilidad de las hablas andaluzas occidentales en los linguistic landscapes de Jerez de la Frontera (provincia de Cádiz). In B. Kern, J. Roger, S. Serafin, \& A. Ch. Thode (Eds.), (Un-)Sichtbarkeiten. Beiträge zum XXXI. Forum Junge Romanistik in Rostock (5.-7. März 2015) (pp. 269-284). München: AVM. 
Harjus, J. (2018). Sociofonética andaluza y lingüística perceptiva de la variación: El español hablado en Jerez de la Frontera. Madrid-Frankfurt a. M.: Iberoamericana Vervuert.

Henriksen, N. C., \& García-Amaya, L. J. (2012). Transcription of intonation of Jerezano Andalusian Spanish. Estudios de Fonética Experimental, 21, 109-162.

Henriksen, N. C., \& Willis, E. W. (2010). Acoustic characterization of phonemic trill production in Jerezano Andalusian Spanish. In M. Ortega-Llebaria (Ed.), Selected Proceedings of the 4th Conference on Laboratory Approaches to Spanish Phonology (pp. 115-127). Somerville, MA: Cascadilla Proceedings Project.

Hernández Campoy, J. M., \& Villena-Ponsoda, J. A. (2009). Standardness and nonstandardness in Spain: Dialect attrition and revitalization of regional dialects of Spanish. International Journal of the Sociology of Language, 196/197, 181-214. https://doi.org/10.1515/IJSL.2009.021

Hundt, M. (2010). Bericht über die Pilotstudie „Laienlinguistische Konzeptionen deutscher Dialekte“. In C. A. Anders, M. Hundt, \& A. Lasch (Eds.), „Perceptual Dialectology“: Neue Wege der Dialektologie (pp. 179-220). Berlin: De Gruyter.

Kabatek, J. (1996). Die Sprecher als Linguisten: Interferenz- und Sprachwandelphänomene dargestellt am Galicischen der Gegenwart. Tübingen: Niemeyer. https://doi.org/10.1515/9783110930979

Kehrein, R., Lameli, A., \& Purschke, C. (2010). Stimuluseffekte und Sprachraumkonzepte. In C. A. Anders, M. Hundt, \& A. Lasch (Eds.), ,Perceptual Dialectology“: Neue Wege der Dialektologie (pp. 351-386). Berlin De Gruyter.

Kontra, M. (2002). Where is the 'most beautiful' and the 'ugliest' Hungarian spoken? In D. Long \& D. R. Preston (Eds.), Handbook of perceptual dialectology: Volume 2 (pp. 207-220). Amsterdam: John Benjamins. https://doi.org/10.1075/z.hpd2.17kon

Krefeld, T. (2005). Sprachbewusstsein, Varietätenlinguistik - und Molière. In D. Jacob, T. Krefeld, \& W. Oesterreicher (Eds.), Sprache, Bewußtsein, Stil. Theoretische und historische Perspektiven (pp. 155-166). Tübingen: Narr.

Krefeld, T. (2010). Italiano, ma popolare? - Einige nicht standardsprachliche Merkmale im Spiegel des Varietätenbewusstseins. In T. Krefeld \& E. Pustka (Eds.), Perzeptive Varietätenlinguistik (pp. 151-180). Frankfurt a. M.: Peter Lang.

Krefeld, T., \& Pustka, E. (2010). Für eine perzeptive Varietätenlinguistik. In T. Krefeld \& E. Pustka (Eds.), Perzeptive Varietätenlinguistik (pp. 9-18). Frankfurt a. M.: Peter Lang.

Krefeld, T., \& Pustka, E. (2014). Welt, Wahrnehmung, Sprache: Die perzeptive Grundlage der Linguistik. In T. Krefeld \& E. Pustka (Eds.), Perzeptive Linguistik: Phonetik, Semantik, Varietäten (pp. 9-18). Stuttgart: Franz Steiner.

Kuckartz, U. (2014). Mixed Methods - Methodologie, Forschungsdesigns und Analyseverfahren. Wiesbaden: Springer. https:// doi.org/10.1007/978-3-531-93267-5

Lenz, A. N. (2010). Zum Salienzbegriff und zum Nachweis salienter Merkmale. In C. A. Anders, M. Hundt, \& A. Lasch (Eds.) „Perceptual Dialectology": Neue Wege der Dialektologie (pp. 89-110). Berlin: De Gruyter.

Lynch, K. (2001) [1965]). Das Bild der Stadt. Gütersloh: Bertelsmann.

Mattheier, K. J. (1996). Varietatenkonvergenz: Überlegungen zu einem Baustein einer Theorie der Sprachvariation. Sociolinguistica, 10(1), 31-52. https://doi.org/10.1515/9783110245158.31

Moreno Fernández, J., \& Moreno-Fernández, F. (2002). Madrid perceptions of regional varieties in Spain. In D. Long \& D. R. Preston (Eds.), Handbook of perceptual dialectology: Volume 2 (pp. 297-322). Amsterdam: John Benjamins. https://doi. org/10.1075/z.hpd2.21mor

Moya Corral, J. A., \& García Wiedemann, E. J. (1995). El habla de Granada y sus barrios. Granada: Universidad de Granada.

Narbona Jiménez, A. (Ed.) (2013): Conciencia y valoración del habla andaluza. Sevilla: Universidad Internacional de Andalucía.

Narbona Jiménez, A., Cano Aguilar, R., \& Morillo Velarde-Pérez, R. (2011). El español hablado en Andalucía. Sevilla: Universidad de Sevilla.
Niedzielski, N. A., \& Preston, D. R. (2000): Folk linguistics. Berlin-New York: Mouton de Gruyter.

Pike, K. L. (1967) (2nd ed.) Language in relation to a unified theory of the structure of human behavior. Den Haag: Mouton.

Piredda, N. (2014). Perzeption des Italienischen in Sardinien: Stadt und Land im Vergleich. In T. Krefeld \& E. Pustka (Eds.), Perzeptive Linguistik: Phonetik, Semantik, Varietäten (pp. 65-85). Stuttgart: Franz Steiner.

Plata, J. de la (1993) (3rd ed.). El habla de Jerez. Vocabulario jerezano enriquecido con nuevos modismos, frases y dichos populares. Cádiz: Diario de Cádiz-Ingrasa.

Postlep, S. (2010a). Zwischen Huesca und Lérida - Perzeptive Profilierung eines diatopischen Kontinuums. Frankfurt a. M.: Peter Lang.

Postlep, S. (2010b). Charrem altramén - Ein aragonesisches 'Randproblem' zwischen aragonés oriental und catalán occidental. In T. Krefeld \& E. Pustka (Eds.), Perzeptive Varietätenlinguistik (pp. 61-102). Frankfurt a. M.: Peter Lang.

Postlep, S. (2012). "Este per no ye d'a mía tierra": Percepción cientifica y percepción inexperta del contínuum dialectal altoaragonés. Alazet, 24, 77-116.

Preston, D. R. (1986). Five visions of America. Language and Society, 15(2), 221-240. https://doi.org/10.1017/S0047404500000191

Preston, D. R. (1989). Perceptual dialectology. Nonlinguists' views of areal linguistics. Dordrecht: Foris.

Preston, D. R. (Ed.) (1999). Handbook of perceptual dialectology: Volume 1. Amsterdam: John Benjamins. https://doi. org/10.1075/z.hpd1

Preston, D. R. (1999). Introduction. In D. R. Preston (Ed.): Handbook of perceptual dialectology: Volume 1 (pp. XXIII-XXXIX). Amsterdam: John Benjamins. https://doi.org/10.1075/z.hpd1.05pre

Preston, D. R. (2005) (2nd ed.). Perceptual dialectology. In U. Ammon, N. Dittmar, K. J. Mattheier, \& P. Trudgill (Eds.), Sociolinguistics: An international handbook of the science of language and society (Vol 2) (pp. 1683-1695). Berlin: De Gruyter.

Purschke, C. (2011). Regionalsprache und Hörerurteil-Grundzüge einer perzeptiven Variationslinguistik. Stuttgart: Franz Steiner.

Pustka, E. (2007). Phonologie et variétés en contact. Aveyronnais et Guadeloupéens à Paris. Tübingen: Narr.

Pustka, E. (2008). Accent(s) parisien(s) - Auto- und Heterorepräsentationen stadtsprachlicher Merkmale. In T. Krefeld (Ed.), Sprachen und Sprechen im städtischen Raum (pp. 213-249). Frankfurt a. M.: Peter Lang.

Ropero Núñez, M. (2001). Sociolingüística andaluza: Problemas y perspectivas. In P. Carbonero Cano \& R. Guillén Sutil (Eds.), Sociolingüistica andaluza 12. Identidad lingüística y comportamientos diversos (pp. 21-48). Sevilla: Universidad de Sevilla.

Ropero Núñez, M., \& Pérez Santamaría, F. J. (1998). Sociolingüística andaluza 11. Análisis estadístico-sociológico de los comportamientos lingüísticos en la ciudad de Sevilla. Sevilla: Universidad de Sevilla.

Scharloth, J. (2005). Sprachnormen und Mentalitäten - Sprachbewusstseinsgeschichte in Deutschland im Zeitraum von 17661785. Tübingen: Niemeyer.

Schirmunski, V. (1928-1929). Die schwäbischen Mundarten in Transkaukasien und Südukraine. Teuthonista, 5, 38-60.

Schlieben-Lange, B. (1991) (3rd ed.). Soziolinguistik - eine Einführung. Stuttgart-Berlin-Köln: Kohlhammer-Urban.

Serrano Morales, J. C. (2001). Cuántos dialectos del español existen en México? Un ensayo de dialectología perceptual. Retrieved from http://lef.colmex.mx/Sociolinguistica/Cambio $\% 20 y \% 20$ variacion/Ensayo $\% 20 \mathrm{de} \% 20$ dialectologia $\% 20$ perceptual.pdf.

Sibata, T. (1999 [1959]). Consciousness of dialect boundaries. In D. R. Preston (Ed.), Handbook of perceptual dialectology: Volume 1 (pp. 39-62). Amsterdam: John Benjamins. https://doi. org/10.1075/z.hpd1.11sib

Sinner, C. (2014). Varietätenlinguistik - eine Einführung. Tübingen: Narr.

Spiekermann, H. (2010). Visualisierungen von Dialekten: ein Beitrag zum Nutzen der Laiendialektologie. In C. A. Anders, M. Hundt, \& A. Lasch (Eds.), „Perceptual Dialectology": Neue Wege der Dialektologie (pp. 221-244). Berlin: De Gruyter. 
Stoeckle, P. (2014). Subjektive Dialekträume im alemannischen Dreiländereck. Hildesheim: Olms.

Torgersen, E. (2012). A perceptual study of ethnicity and geographical location in London and Birmingham. In S. Hansen, C. Schwarz, P. Stoeckle, \& T. Streck (Eds.), Dialectological and folk dialectological concepts of space: Current methods and perspectives in sociolinguistic research on dialect change (pp. 75-95). Berlin: De Gruyter. https://doi.org/10.1515/9783110229127.75

Torres Montes, F. (1997). Actitudes lingüísticas en la ciudad de Almería. In A. Narbona Jiménez \& M. Ropero Núñez (Eds.), El habla andaluza. Actas del Congreso del habla andaluza (pp. 635-646). Sevilla: Seminario Permanente del Habla Andaluza.

Villena Ponsoda, J. A. (1996). Convergence and divergence in a standard dialect continuum: Networks and individuals in Málaga. In P. Auer, F. Hinskens, \& K. Mattheier (Eds.), Konvergenz und Divergenz von Dialekten in Europa (pp. 112-137). Tübingen: Niemeyer.
Villena-Ponsoda, J. A. (2008). Sociolinguistic patterns of Andalusian Spanish. International Journal of the Sociology of Language, 193/194, 139-160. https://doi.org/10.1515/IJSL.2008.052

Villena Ponsoda, J. A. (2012). Patrones sociológicos del español de Andalucía. In J. A. Villena Ponsoda \& A. M. Ávila Muñoz (Eds.), Estudios sobre el español de Málaga: Pronunciación, vocabulario y sintaxis (pp. 27-66). Málaga: Sarriá.

Weijnen, A. A. (1999 [1946]). On the value of subjetive dialect boundaries. In D. R. Preston (Ed.), Handbook of perceptual dialectology: Volume 1 (pp. 131-133). Amsterdam: John Benjamins. https://doi.org/10.1075/z.hpd1.16wei

Williams, A., \& Garrett, P., \& Coupland, N. (1999). Dialect recognition. In D. R. Preston (Ed.), Handbook of perceptual dialectology: Volume 1 (pp. 345-358). Amsterdam: John Benjamins. https://doi.org/10.1075/z.hpd1.29wil

Woehrling, C., \& Boula de Mareüil, P. (2006). Identification d'accents régionaux en français: perception et catégorisation. Bulletin PFC, 5, 89-102. 